\title{
Health Policy and the Law in Senegal
}

Francis G. Snyder

Follow this and additional works at: http://digitalcommons.osgoode.yorku.ca/ohlj Article

\section{Citation Information}

Snyder, Francis G.. "Health Policy and the Law in Senegal." Osgoode Hall Law Journal 11.1 (1973) : 127-155.

http://digitalcommons.osgoode.yorku.ca/ohlj/vol11/iss1/9

This Article is brought to you for free and open access by the Journals at Osgoode Digital Commons. It has been accepted for inclusion in Osgoode Hall Law Journal by an authorized editor of Osgoode Digital Commons. 


\title{
HEALTH POLICY AND THE LAW IN SENEGAL*
}

\author{
By FRANCIS G. SNYDER *****
}

\section{INTRODUCTION}

The improvement of health facilities is among the most urgent and critical areas of public policy in developing countries. All may appreciate Barbara Ward's affirmation that the "inconceivably great contribution of health makes development irreversible". ${ }^{1}$ However one defines "development", 2 the availability of adequate health service appears as a necessary precondition to the realization of man's fullest potential. ${ }^{3}$

This article considers some aspects of health policy and the law in the developing country of Senegal. Located on the western coast of Africa, Senegal is bordered by the Islamic Republic of Mauritania on the north, the Republic of Mali on the east, and the Republic of Guinea and the territory of Guinea-Bisseau on the south. Its area of approximately 196,192 square kilometers ${ }^{4}$ is inhabited by an estimated total of 3,780,000 people. 5 Formerly part of the French colonial federation of French West Africa (A.O.F.), Senegal formed the Federation of Mali with the former French Sudan on 17 January 1959. With the failure of

* This article, shortly to be published in Social Science and Medicine, is being substantially reprinted here by kind permission of the Editor of that journal.

* Assistant Professor, Osgoode Hall Law School and Division of Social Science, York University.

*** The author is grateful to Eric Switzer and David Zacks for their contributions to this article and to Professor P. W. Hogg for his helpful comments.

1 Barbara Ward, "Development: The Irreversible Revolution", in van Zile Hyde, ed., Manpower for the Nation's Health (Report of the Institute on International Medical Education, Association of American Medical Colleges, Washington, D.C., March 27-30, 1966); (1966) The Journal of Medical Education 5 at 7.

2 Normative, economic, organizational and instrumental definitions of development are compared by Denis Goulet, "That Third World", in H. Castel, ed., World Development (New York: Macmillan, 1971) at 1-24.

${ }^{3}$ See J. Bryant, Health and the Developing World (Ithaca: Cornell University Press, 1969) at 312-13. The case for including a substantial health component in development programs is cogently argued in W. McDermott, "Modern Medicine and the DemographicDisease Pattern of Overly Traditional Societies," in H. van Zile Hyde, ed., Manpower for the Nation's Health, supra, note 1, 137 at 148-50. at 81 .

${ }^{4}$ Statistical Yearbook 1970 (New York: United Nations Publishing Service, 1971)

5 République du Sénégal, Ministère du Plan et de L'Industrié, Troisième Plan Quadriennal de Développement Economique et Social 1969-1973 (Dakar: Imprimerie A. Diop, 1969) [hereinafter cited as Troisième Plan] at 8. This estimate as of 30 June 1969 is based on an estimated annual increase of $2.2 \%$ since the 1961 census of 3,109,840, itself based on a sample of the population. 
this political entity on 20 August 1960, Senegal became politically independent by the adoption of its constitution on 25 August 1960.6

Leaving aside the questions of nutrition and sanitation, several types of health problems form the background to the discussion of health policy and the law in Senegal. Certain diseases are endemic to most of Senegal with the exception of the capital city: bilharzia, trachoma, malaria and leprosy. ${ }^{7} \mathrm{~A}$ number of other illnesses or infections are common, including blindness, cerebrospinal meningitis, fevers of the typhus group, intestinal infections, parasitic worm and helminthic diseases, tropical ulcer, tuberculosis and venereal diseases. ${ }^{8}$ The infant mortality rate, while relatively low for West Africa, is high in comparison with that of rich countries and forty per cent of the children born alive die before the age of five years. ${ }^{9}$

Since legal aspects of public health in Africa have previously received little scholarly attention, the present article should be regarded as a preliminary incursion into this important domain. Its primary purpose is to provide a general survey of the contemporary Senegalese law relating to public health. In .order to do so, it will be necessary to trace the gradual evolution of this body of law, indicating the principal areas of endeavour in which legislation has been and is being used to further first colonial and then national goals. The limited scope of this article precludes a discussion of the legal aspects of nutrition and sani-

6 See W. J. Foltz, From French West Africa to the Mali Federation (New Haven: Yale University Press, 1965); 2 P. F. Gonidec, Droit d'Outre-Mer (Paris: Editions Montchrestien, 1959) at 437-42, P. Lampué, Droit d'Outre-Mer et de la Coopération (4e édition Paris: Dalloz, 1969) at 188, D. G. Lavroff, La République du Sénégal (Paris: Librairie Générale de Droit et de Jurisprudence, 1966) at 22-47.

7 See M. Sankalé and P. Pené, Médecine Sociale au Sénégal (Dossiers Africains, Supplements d' Afrique Documents, Cahier 1, Mars 1960) at 10-11. In 1952, an order of the AOF Government-General declared all of French West Africa, with the exception of the Cap Vert area which included Dakar, a zone of permanent endemnicity for smallpox, yellow fever, sleeping sickness and leprosy (AGG no. 4981 S.P. du 12 août 1952, désignant les chefs de territoires pour fixer périodiquement, par arrêté, les zones de dépistage des maladies endémiques, variole, fièvre jaune, trypanosomiase et lèpre [1952 Journal Officiel de l'Afrique Occidentale Francaise [hereinafter cited as JOAOF] at 1174]. By 1959 yellow fever and smallpox had been largely eradicated as a result of colonial health policies to be discussed infra. The incidence of sleeping sickness, first noted in Senegal in 1877, A. Sice, La trypanosomiase humaine en Afrique intertropicale (Paris: Vigot Frères, 1937) at 5, was decreasing. 1 Compagnie d'Etudes Industrielles et d'Amenagement du Territoire (C.I.N.A.M.) et Societe d'Etudes et de Réalisations Economiques et Sociales dans l'Agriculture (S.E.R.E.S.A.), Rapport général sur les perspectives de développement au Sénégal (Dakar: J. et Ch. Bompard, 3e édition janvier 1963) [hereinafter C.I.N.A.M.S.E.R.E.S.A.] 1-4(21).

8 Lord Hailey, An African Survey, Revised 1956 (London: Oxford University Press, 1957) [hereinafter cited as Hailey] at 1069-72, 1108-32 describes the principal diseases common to Africa as a whole. See also R. F. Gray, "Medical Research: Some Anthropological Aspects", in R. A. Lystad, ed. The African World (New York: Praeger, 1965) at 352. See also C. H. Hughes and J. M. Hunter, Disease and "Development" in Africa (1970), Social Science and Medicine 443; M. Payet, P. Pené, M. Sankalé, et al., Cliniques africaines (Paris: Gauthier-Villars, 1966); T. R. Harrison, R. D. Adams, I. L. Bennett, Jr., W. H. Resnik, G. W. Thorn, and M. M. Wintrobe, eds., Principles of Internal Medicine (New York: McGraw-Hill, 5th ed. 1966).

9 S. Diarra, La population du Senegal (1971), 33 Bulletin de l'Institut Fondamental d'Afrique Noire 642 at 656. 
tation, both intimately related to public health. Nor is it possible in this preliminary survey to consider in detail the manifold social, political, and economic factors which help shape Senegalese public health law and, to a large degree, determine the manner and extent of its application. Finally it will not be feasible to consider here the question of the extent to which Senegal is typical of African countries in respect of its law relating to public health..$^{10}$

In developing a legal framework within which to meet the health needs of the population, the Senegalese government has necessarily been influenced by certain constraints resulting from French health policies during the colonial period. ${ }^{11}$

\section{THE COLONIAL PERIOD}

Although the first French establishments in Senegal date from 1638, not until the late nineteenth century was the French military position in the area consolidated. The French Civil Code was introduced in 1830. A series of

10 That some of the questions to be considered in this article are not unique to Third World countries is evident in Rudy Platiel, "How a village built itself a health service", The Globe and Mail (Toronto), September 21, 1972 at 47. Two particularly important questions which deserve further consideration in the Senegalese context are, first, the relationship and potential contribution of indigenous African medical knowledge and skills to the planning of national health care and, secondly, legal aspects of health planning in urban areas. Leaving aside the field of psychiatry, a basis for research on the first question is provided by E. H. Ackerknecht, Problems of Primitive Medicine (1942), 11 Bulletin of the History of Medicine 503; E. H. Ackerknecht, Natural Diseases and Rational Treatment in Primitive Medicine (1946), 19 Bulletin of the History of Medicine 467; Special Issue on Rural Health in Africa (1972), 17 Rural Africana; J. B. N'Diaye, Végétaux utilisés dans la médecine africaine de la région de Richard-Toll (Sénégal) (1962), 93 Notes Africaines 14; J. Kerharo and J. G. Adam, Plantes médicinales et toxiques des Peul et des Toucouleur du Sénégal (1964), 11 Journal de l'Agriculture tropicale et de botanique appliquée 338, 12 id 543; J. Kerharo and L. V. Thomas, La médecine traditionnelle des Diola de Basse-Casamance (1963), 70-71 Afrique Documents 167; J. Kerharo, Le facteur magico-religieux dans l'exercice de la médecine traditionnelle en milieux sénégalais (1969) 5 Psychopathologie africaine 269; V. Turner, "Lunda Medicine and the Treatment of Disease" and "A Ndembu Doctor in Practice", in The Forest of Symbols (Ithaca: Cornell University Press, 1967) at 299 and 359, respectively. On the contribution of traditional medicine to modern mass medical education see P. Fougeyrollas, Modernisation des hommes, l'exemple du Sénégal (Paris: Flammarion, 1967) at 176-201. The vast literature available for further research on the second problem includes Special Health Issue (1969), 4 African Urban Notes (2); A. H. Walsh, Urban Local Government in French-Speaking Africa (1969), 4 African Urban Notes (4) at 1; R. F. Betts, The Problem of the Medina in the Urban Planning of Dakar, Senegal (1969), 4 African Urban Notes (3) at $5 ; A$ Bibliography of Published Materials on the History of Dakar, Senegal (1969), 4 id. at 16; M. Sankalé, R. Baylt, H. Collomb, H. Ayats, H. Ba and J. Cros, "Urbanisation et santé", in Groupé d'études Dakaroises, Dakar en devenir (Paris: Présence Africaine, 1968) at 265-97.

11 The choice of such a point of departure is not intended to minimize the potential contribution to Senegalese health services of African medical skills predating the colonial era. See supra note 10. This article is concerned with national law and policy. 
decrees between 1895 and 1904 grouped Senegal with other French colonies in West Africa in the federation known as French West Africa (A.O.F.). ${ }^{12}$

Within the framework of certain more or less clearly articulated goals the French after 1904 established a health administration entrusted with effectuating public health policies in their West African colonies, including Senegal.

\section{A. General Purposes of Colonial Health Policy}

The recognition by the French in West Africa of the desirability of a coherent social welfare policy, including the provision of health and educational facilities, was the result of the convergence of several factors in the early twentieth century.

During the early period of European exploration in Africa, West Africa and other areas of the continent in which malaria was hyperendemic were frequently known as the "white man's grave". ${ }^{13}$ The outbreak of a yellow fever epidemic in Senegal in 1900 resulted in a Yellow Fever Vaccination Scheme in French West Africa. ${ }^{14}$ This scheme, like the majority of French colonial health services until after 1910, had as its basic purpose the provision of preventive and curative medical facilities for Europeans in the colonies. ${ }^{15}$

The European population in French African colonies was minute in relation to the African population. Such was particularly the case at the opening of this century when in 1908 an estimated twelve hundred Europeans claimed to govern an African population of fifteen million. ${ }^{16} \mathrm{It}$ is therefore not surprising that if the French were to reap any economic benefits from West Africa they were necessarily to be heavily dependent on mobilizing the labour of the African population. The question of available manpower became especially acute from 1906 to 1914 "when French colonial policy in Africa was dominated by the idea of providing ' $a$ reservoir of men' for military purposes."17 Consequent manpower requirements dictated efforts to improve the African population both

12 See J. D. Hargreaves, West Africa: The Former French States (Englewood Cliffs, N.J.: Prentice-Hall, 1967) at 59-87, 92-97; J. W. Salacuse, A Background to Law in FrenchSpeaking West Africa (1969), African Law Studies (Preliminary Issue), 1-10, 12-13, 22-36; M. Crowder, West Africa Under Colonial Rule (London: Hutchinson, 1968) [hereinafter cited as Crowder] at 174-80.

13 R. F. Gray "Medical Research: Some Anthropological Aspects", supra, note 8.

14 Crowder, supra, note 12 at 285 . This epidemic resulted in the deaths of all Europeans at the relatively isolated commercial and administrative post of Carabane in the Casamance area; d'Anfreville de la Salle, Sur la cote d'Afrique (Paris: E. Larose, 1912) at 206.

15 As early as 1853 colonial administration facilities in Saint-Louis, an early French base in Senegal, included a large naval hospital; M. Crowder, Senegal, A Study of French Assimilation Policy (London: Methuen, revised edition 1967) at 15, citing Abbé Boilat, Esquisses Sénégalaises (Paris: P. Bertrand, 1853) at 206-07.

16 R. Delavignette, Freedom and Authority in French West Africa (London: Frank Cass, new impression, 1968; trans. of Service Africain, originally published in Paris, Editions Gallimard, 1946) at 18.

17 S. Roberts, The History of French Colonial Policy, 1870-1925 (London: Frank Cass, 1963; originally published in London: P. S. King and Co., 1929) at 332. 
quantitatively and qualitatively..$^{18}$ The provision of health services for Africans was explicitly directed toward this goal. ${ }^{19}$

In this respect little was accomplished prior to the First World War, though liberal French colonial administrators have always acclaimed the improvement of health facilities for the average African as part of France's "civilising mission" ${ }^{20}$ From the 1920 's on the colonial medical services did contribute to the improvement of health conditions in Africa. ${ }^{21}$ It should also be recalled that Governor-General Ponty noted clearly in 1908 the increased prestige which might be expected to accrue to the French colonial administration by attempts to improve living conditions in the colonies.22

It was also recognised that to the extent that it promoted increased interaction between Africans and the colonial administration, the provision of health services to the African population in Senegal complemented taxation and military force as a means of facilitating minority control of the largely rural population of West Africa. ${ }^{23}$

\section{B. Public Health Administration}

Consistently with the principles of French colonial administration ${ }^{24}$ public health services in West Africa were organised in a centralised bureaucratic pattern. Colonial medical services were unified in the Corps des Médecins de la Santé de la France d'Outre-Mer with headquarters in the Ministry for Overseas France in Paris. Colonial health services were under the control of a Direction Générale in Paris. General responsibility for colonial health services was in fact vested in the Service de Santé des Troupes Coloniales. ${ }^{25}$ From 1904

18 S. Roberts, The History of French Colonial Policy, 1870-1925, supra, note 17 at 332-34; Hailey, supra, note 8 at 1105.

19 Even in $1926 \mathrm{~J}$. G. Carde, then Governor-General of French West Africa, reaffirmed that: "Le but à atteindre est de développer les races indigènes en qualité et en quantité;" 2 R. L. Buell, The Native Problem in Africa (London: Frank Cass, 1965; originally published in Cambridge, Mass.: Bureau of International Research of Harvard University and Radcliffe College, 1928), [hereinafter cited as Buell], Appendix XXVII: "Instructions to the French Medical Service. Instruction relatif à l'orientation et au développement des services d'assistance médicale indigène," at 190.

20 R. Delavignette, Freedom and Authority in French West Africa, supra, note 16 at 22. See generally Crowder, supra, note 12 at 5-6.

$21 \mathrm{R}$. Girard, "La Situation sanitaire et démographique dans l'Union francaise" in Congrès Mondial des Médecins pour l'Etude des Conditions Actuelles de Vie, Rapports et Communications (23-25 Mai 1953, Vienne) (Vienne, Secrétariat International du Congrès, 1953) 22-37.

22 "Everything we can do to improve his moral and physical well-being will profit our prestige and culture." Speech to the Conseil du Governement, February 18, 1908, cited in Crowder, supra, note 12 at 283.

23 d'Anfreville de la Salle, Sur la cote d'Afrique, supra, note 14 at 216-17.

24 See P. F. Gonidec, 1 Droit d'Outre-Mer (Paris: Editions Montchrestien, 1959); L. G. Cowan, Local Government in West Africa (New York: Columbia University Press, 1958); 1 J. W. Salacuse, An Introduction to Law in French-Speaking Africa: Africa South of the Sahara (Charlottesville: The Michie Company, 1969).

25 Payet, "L'Enseignement médical universitaire en A.O.F." in Conferences Internationales Médicales de Dakar sur la Coopération médicale et sur l'Enseignement médical (Dakar, 16-24 mai 1951) (Paris: La Documentation francaise, 1952) [hereinafter Conférences Internationales Médicales] 86-90 at 86. 
the administrative heads of individual territories in French West Africa were given broad powers and responsibilities in public health matters in their respective territories. ${ }^{25 a}$

In 1913 a Direction Fédérale for public health was created at the capital of each of the two major groupings of French colonies in Africa, French West Africa and French Equatorial Africa. Dakar was the headquarters of the Chief of Sanitary Services for French West Africa.

Health services in each of the constituent territories of these two federations were under the supervision of a Direction Locale. For the purposes of health administration, Dakar, the capital of French West Africa was considered a separate territory with its own Direction Locale. The Direction Locale for Senegal was located at Saint-Louis. ${ }^{25 b}$ Each territory had a chief medical officer whose duties comprised, inter alia, the supervision of medical officers in charge of the local medical districts, the lowest level of the hierarchy. Each medical district was to correspond with a local administrative district (circonscription).

Within each territory the health services included two distinct organizations. One, the Service de l'Assistance Médicale Africaine, fell under the control of the territory's Direction Locale and was directly responsible for all health questions except those involving the major endemic diseases. Control of these diseases was the task of a second organization, the Service Général d'Hygiène Mobile et de Prophylaxie (S.G.H.M.P.), which as a federal service was directly responsible not to the territorial health authorities but to the Direction Fédérale. ${ }^{26}$

\section{Colonial Public Health Policies}

In respect of the health policies of the European colonial powers in Africa two schools of thought have been distinguished. The first, often associated with the British, preferred to attempt to meet health needs by the proliferation of hospitals. The second, of which the French in Africa were typical, laid greater emphasis on the establishment of dispensaries and anti-epidemic organizations, both of which could be staffed by persons with less medical training than that required for staffing hospitals. The difference between these two schools did not coincide exactly with the distinction between curative and preventive medicine but rather reflected divergent views as to the manner in which to allocate limited resources. 27

The major thrust of public health policy in Senegal before 1960 may be therefore most conveniently seen by considering in turn anti-epidemic measures, the extension of health services in rural areas, and the training of medical personnel before summarising the state of medical facilities generally in Senegal immediately prior to independence.

25a Décret du 14 avril 1904 relatif à la protection de la salubrité publique en Afrique occidentale française [1906 JOAOF 293].

25b Hailey, supra, note 8 at 1086; R. Girard, "La Situation sanitaire et démographique dans l'Union française" supra, note 21 at 32.

$26 \mathrm{H}$. Jonchère, "La Coopération médicale entre le Service Générale d'Hygiène Mobile et de Prophylaxie en A.O.F. et les services sanitaires étrangers", Conférences Internationales Médicales, supra, note 25 at 16-17.

27 Hailey, supra, note 8 at 1105-06. 


\section{Anti-Epidemic Measures}

Among the first priorities of colonial health policy was the control and eradication of epidemic diseases. As early as 1911 the reporting to administrative authorities of cases of certain epidemic and endemic diseases was exempted from professional privilege and made obligatory..$^{28}$ Numerous decrees and ministerial orders sought to eradicate stagnant water and other conditions conducive to the breeding of yellow fever vectors and to establish means of controlling the spread of typhus, yellow fever, smallpox, and other diseases. ${ }^{29}$

An integral part of these measures was medical research. ${ }^{30}$ Research into tropical diseases and programmes for the eradication of epidemics have been among the major contributions of French colonial policies to the improvement of health conditions in Africa. ${ }^{31}$

28 Arrêté ministériel du 7 février 1911 fixant la liste des maladies dont la déclaration est obligatoire aux colonies [1911 JOAOF 237].

29 Décret du 18 octobre 1911 déterminant les pénalités pour infractions aux arrêtés relatifs aux eaux stagnantes dans l'intérieur des villes en Afrique occidentale française [1911 JOAOF 753]; Décret du 6 mai 1922 [1922 JOAOF 341]; A.G.G. du 15 octobre 1927 fixant les mesures destinés à prévenir ou à faire cesser les épidémies de thyphus amaryl en Afrique occidentale française [1927 JOAOF 715]; Décret du 22 novembre 1927 abrogeant et remplacant le décret du 27 septembre 1927 sur la protection de la santé publique en Afrique occidentale française [1927 JOAOF 871]; Décret du 16 juin 1931 [1931 JOAOF 644]; A.G.G. no. 1 A.P.A. du 1 janvier 1928 relatif à l'exécution des préscriptions sanitaires lorsque la personne responsable s'absente de la localité pour une durée supérieure à huit jours [1928 JOAOF 7]; Circulaire no. 90 S.S.M. du 23 mars 1933 au sujet de l'organisation de la campagne pré-amaryle [1933 JOAOF 345]; A.G.G. no. 212 S.S.M. du 13 janvier 1933, portant réglementation des mesures d'ordre spécial, temporaire et défensif, destinées à prévenir ou à faire cesser les épidémies de typhus amaryl en Afrique occidentale française [1933 JOAOF 346]; A.G.G. no. 1502 S.S.M. du 31 janvier 1933 portant réglementation des mesures d'ordre special, temporaire et défensif, destinées à prévenir ou à faire cesser les épidémies de typhus amaryl en Afrique occidentale française [1937 JOAOF 659]; A.G.G. no. 2112 S.S.M. du 2 août 1937 [1937 JOAOF 871]; A.G.G. no. 3521 S.S.M. du 2 décembre 1937 portant reglementation du trafic ferroviaire en periode de fièvre jaune [1937 JOAOF 1347]; A.G.G. no. 1804 S.S.M. du 2 juin 1938 [1938 JOAOF 740]; A.G.G. no. 2996 S.S.M. du 14 septembre 1938 portant dispense à titre strictement personnel à tous sujets présentant une immunité forte à l'egard du virus amaril de certaines mesures édictées par l'arrêté 212 S.S.M. du 23 janvier 1933 [1938 JOAOF 1131], modified by A.G.G. no. 1885 S.P. du 24 mai 1943 [1943 JOAOF 430]; Circulaire no. 1671 S.S.M.-1 du 4 septembre 1939 du Gouverneur-Général de l'A.O.F. définissant les modalités de la Prophylaxie agronomique en Afrique occidentale française, in H. Gascher, Les Glossines de l'Afrique Occidentale Française (Basel: Verlag fur Recht une Gesellschaft A.G., 1945) at 110-115; A.G.G. no. 4980 du 12 août 1952 déclarant zone d'endémicité permanente de variole, de fièvre jaune, de trypanosomiase et de lèpre, le territoire de l'Afrique occidentale française, à l'exclusion d'une partie de la presqu'île du Cap-Vert [1952 JOAOF 1173]; A.G.G. no. 4981 S.P. du 12 août 1952 désignant les chefs de territoires pour fixer périodiquement, par arrêté, les zones de dépistage des maladies endémiques, variole, fievre jaune, trypanosomiase et lèpre [1952 JOAOF 1174]; A.G.G. no. 4982 S.P. du 12 août 1952 rendant obligatoire pour tous les vaccinations antivariolique et antiamaryle [1952 JOAOF 1174]; A.G.G. no. 834 S.P. du 5 fevrier 1953 relatif à la protection de la santé publique [1953 JOAOF 223].

30 "The Pasteur method revolutionized tropical medicine". J. Richard-Molard, Afrique Occidentale Française (Paris: Editions Berger-Levrault, 1952) at 158.

31 M. Crowder, supra, note 12 at 328; Hailey, supra, note 8 at 1088-89. 


\section{Extension of Rural Health Services}

It is perhaps in respect of the role of hospitals in providing rural health services that French colonial policy in matters of public health contrasted most strikingly with British policies. In 1956 Lord Hailey noted that "whereas in the British territories hospitals are regarded mainly as centres for treatment, those in French Africa function largely as headquarters of field stations whence curative and preventive medicine is made available in rural areas." 32

Not until the inter-war years did the colonial health service in Senegal begin to expand systematically into rural areas. ${ }^{33}$ Government circulars of 1921 and 1924 respectively stressed the need to concentrate on preventive instead of only curative medicine ${ }^{34}$ and to develop a staff of African auxiliaries whose major task was to be public-health propaganda. ${ }^{35}$ Ministerial instructions of 30 December 1924 confirmed these circulars and redirected the colonial medical services in principle toward mass preventive medicine with special attention to rural areas. ${ }^{36}$ By 1936 each cercle had at least one medical centre staffed by a European doctor with dependent dispensaries supervised by auxiliary personnel in the surrounding rural areas. ${ }^{36 a}$

In addition to general colonial health policy and availability of medical establishments, ${ }^{37}$ the fee structure of health institutions also discouraged African use of hospitals for in-patient treatment and encouraged recourse to hospital out-patient treatment and, more importantly, to local dispensaries and maternity clinics. Hospital in-patient treatment was free only to the indigent, although rates were graduated according to the income of patients. Out-patient treatment was free to Africans. ${ }^{37 a}$

\section{Medical Personnel and Training}

A major factor dictating and limiting the extension of health facilities in rural areas was that of medical personnel. ${ }^{38} \mathrm{It}$ has been remarked that "the French tackled the battle for health as a military operation". ${ }^{39}$ Not only were health services hierarchically organized but a large number of European

32 Hailey, supra, note 8 at 1086.

33 Crowder, supra, note 12 at 285.

34 Circulaire no. 19 of 12 April 1921 of Governor-General Merlin, cited in 2 Buell, supra, note 19 at 189.

35 Circulaire of 12 March 1924 of Governor-General Carde, cited in 2 Buell, supra, note 28 at 189. See also Hailey, supra, note 8 at 1087.

36 See 2 Buell, supra, note 19 at 189-90.

36a Crowder, supra, note 12 at 327.

37 Though by 1936 there were only 11 hospitals for all of A.O.F., the area was served by 437 provisional medical establishments and dispensaries staffed by 185 African auxiliary doctors and 30 European and 250 African health visitors. See Crowder, supra, note 12 at 327.

37a Hailey, supra, note 8 at 1088.

38 E. Sére de Rivières, Le Sénégal - Dakar (Paris: Editions Maritimes et Coloniales, 1953) at 64; J. Richard - Molard, supra, note 30 at 157-58.

39 Crowder, West Africa Under Colonial Rule, supra, note 12 at 327. 
medical personnel were members of the army. ${ }^{40}$ Prior to World War I, there were about 110 European doctors for all of French West Africa. By 1925 the number had increased to 133 . About half of them were military doctors assigned to civilian medical duty and half were civilian doctors. Despite the use of military doctors, the number of European medical personnel was inadequate. Even the post-1925 quota of 165 doctors for the French West African Federation provided an average of only one European doctor for 72,000 people. ${ }^{41}$

As a consequence of the small number of European doctors a major share of responsibility for health care devolved upon subordinate personnel. This is evident in the relative number of hospital visits and dispensary consultations in 1924. About 13,523 people were admitted to hospitals for a total of 346,540 days, while 391,940 persons were treated in dispensaries for a total of 2,213,484 consultations, and 1,617,508 vaccinations were given. The following year the number of consultations increased to $3,369,585.42$ Staffing of these facilities in rural areas required the development of a corps of medical auxiliaries. ${ }^{43}$

In 1918 a school for African medical auxiliaries, or auxiliary doctors, opened at Dakar ${ }^{44}$ in connection with the African hospital there. Based on French experience in Madagascar and the Far East, the Ecole de Médecine de Dakar ${ }^{45}$ was divided into medical, veterinary, pharmaceutical and obstetrical sections. ${ }^{46}$ Teachers were drawn largely from doctors at the hospital. Students were chosen by competitive examinations from among graduates of the famous Ecole Normale William-Ponty. ${ }^{47}$ The number of potential entrants was small. From 1918 to 1945 less than two thousand students from all parts

40 Throughout most of the colonial period military doctors occupied the upper echelon posts of the colonial public health service in French West Africa. See the agenda of reports presented at the Conférences Internationales Médicales at Dakar in 1951 in Conférences Internationales Médicales, supra, note 25 at 16 and 80-81. The Ecole Africain de Médecine et de Pharmacie de Dakar was established by the Service de Santé des Troupes coloniales. Payet, "L'Enseignement medical universitaire en A.O.F.", in Conférences Internationales Médicales, supra, note 25 at 86.

412 Buell, supra, note 19 at 36-37.

422 Buell, supra, note 19 at 36.

43 The French paid more attention to the training of subordinate African medical personnel than did the British. See 2 Buell, supra, note 19 at 40 . For a good discussion of the analogous Belgian policy in the former Belgian Congo, see W. DeCraemer and R. C. Fox, The Emerging Physician (Stanford: The Hoover Institution, 1968).

44 Décret du 14 janvier 1918 [1918 JOAOF 56].

45 Subsequently named the Ecole Africaine de Médecine et de Pharmacie until 1950 when, as the Ecole Préparatoire de Médicine et de Pharmacie, it became part of the Institut des Hautes Etudes de Dakar, which obtained university status in 1953. Hailey, supra, note 8 at 1195-96. See Bergeret, "L'Ecole Africaine de Médecine et de Pharmacie de Dakar," in Conférences Internationales Médicales, supra, note 25 at 81, and Payet, "L'Enseignement médical universitaire en A.O.F.," in id at 86.

46 Arrêté du 1 mai 1924 [1924 JOAOF 366].

47 On the importance of the Ecole Normale William Ponty in French West Africa, see Thomas Hodgkin and Ruth Schachter, French-Speaking West Africa in Transition, International Conciliation, 528, May 1960, 375 at 384-387. Ruth Schachter Morgenthau, Political Parties In French-Speaking West Africa 10-22 (Oxford: Clarendon Press, 1964). F. G. Snyder, One-Party Government in Mali (New Haven: Yale University Press, 1965). 
of French colonial Africa graduated from Ponty. About one-third of these were later trained as medical assistants. ${ }^{48}$

After approximately eight years of prior education, culminating in graduation from Ponty school, 49 medical students at Dakar were required to complete a course either of four years for auxiliary doctors or of three years for midwives, veterinary students and pharmacists. ${ }^{50}$ This course of study 51 emphasized practical work. ${ }^{52}$ Graduates were placed in charge of rural dispensaries under the general supervision of European medical officers, while midwives were given responsibility for maternity centres. ${ }^{53}$

Medical education at Dakar covered only the first three years of six required in France. Hence until Senegalese independence the Ecole Préparatoire de Médecine et de Pharmacie was, as its name implied, "an institution for preliminary studies."54 For more advanced studies necessary for qualification as a fully-fledged physician, Africans were thus obliged to continue their studies in France..$^{55}$ Such a policy institutionalized a distinction between those medical personnel who were fully-trained in terms of French medical education and those whose training, partial in terms of the French system of medical education, channelled them into subordinate roles in the colonial medical hierarchy. During the colonial period the former group was composed almost exclusively of Europeans and the latter of Africans. The provision of medical training facilities for Africans was thus consistent with the more general French colonial policy in education of training Africans to meet the needs of the colonial administration in respect of subordinate personnel ${ }^{56}$ and of concentrating, to a greater extent than the British, on vocational education. ${ }^{57}$

Colonial medical education provided also for the training of less qualified personnel. In addition to pharmacists and midwives, the Ecole de Dakar

48 From its creation until 1950 the Ecole Africaine de Médecine et de Pharmacie de Dakar trained 514 medical assistants, 50 pharmacists, and 481 midwives; Bergeret, "L'Ecole Africaine de Médecine et de Pharmacie de Dakar," in Conférences Internationales Médicales, supra, note $25,81-85$ at 81 . Id., at 84 gives statistics as to the number of graduates annually from 1921 to 1953.

49 The school system of colonial French West Africa is discussed in Hailey, supra, note 8 at $1193-1202$.

502 Buell, supra, note 19 at 38 .

51 The pre-1925 course of instruction for all sections of the Ecole de Médecine de Dakar is set out in 2 Buell, supra, note 19 at 204-07: Appendix XXVIII: Program of Instruction-Dakar Medical School.

522 Buell, supra, note 19 at 38.

532 Buell, supra, note 19 at 39 .

54 Hailey, supra, note 8 at 1098.

55 For a discussion of the manifest and latent conflicts in such a situation, see $C$. Guy, L'évolution de l'enseignement en Afrique occidentale française (1924), 34 Bulletin du Comité de l'Afrique française 438; B. Dadié, Misère de l'enseignement en A.O.F. (1956-57) Présence Africaine 57; A. Sar, I. Fofana and K. Banny, Esprit et situation de l'enseignement en A.O.F. (1956-57), Présence Africaine 71.

56 See M. DeBeauvais, "Education in Former French Africa," in J. S. Coleman, ed., Education and Political Development (Princeton: Princeton University Press, 1965) 75-91.

57 R. P. Clignet and P. J. Foster, French and British Colonial Education in Africa (1964), Comparative Education Review 191 at 195. 
provided courses for male and female nurses and gardes sanitaires. Male nurses could gain access to a specialist grade by further training in pharmacy and medical or laboratory work. The Ecole Jamot in Upper-Volta, after 1949 incorporated in the Centre d'Etudes des Trypanosomiases Africaines at BoboDioulasso, provided special preparation for work on the mobile medical service (S.G.H.M.P.) by a normal course of nine months and short courses of two or three months. Leprosy training was available at the Institut Marchoux in Bamako, French Sudan, now Mali. 58

\section{Medical Facilities in the 1950's}

By 1951 French West Africa had a total medical personnel composed of 216 registered physicians and 376 medical assistants, pharmacists and midwives. All physicians as of 1950 were Europeans. One was employed by a Mission and thirty were employed by business firms. ${ }^{59}$ In all of French West Africa and Togo only nineteen doctors were in private practice. 60 The 1006 institutions for treatment included eight hospitals (one for Europeans and one for Africans at Dakar), 19 smaller establishments, 152 medical centres, 232 Government and 23 other dispensaries, and 107 maternity institutions. ${ }^{61}$

At this time the health infrastructure in Senegal was composed of major hospital complexes at Dakar, Saint-Louis, Kaolack and Ziguinchor; minor hospitals at Thiès, Rufisque, and Tambacounda; and 30 secondary treatment centres and 120 rural dispensaries. Five mobile hygiene teams were concerned primarily with epidemics. Non-governmental facilities included eleven Catholic mission dispensaries and two Red Cross dispensaries. Six quarantine stations and 42 maternity facilities completed medical facilities available in Senegal.62

Immediately prior to Senegalese independence an extensive study of the country by two French research organizations was commissioned in order to provide basic information for social and economic planning. With respect to public health the study distinguished two types of facilities, those for individual treatment and mobile hygiene and prophylactic units. A single branch (hospitals) of the former absorbed two-fifths of the Sengalese health budget yet the major health problems of the country could, in the view of the report, be met only by the latter. ${ }^{63}$ Consequently the research group recommended that rural mass medicine, general health and sanitary education, and eradication of endemic diseases continue to be given priority in the period following independence. ${ }^{64}$

58 Hailey, supra, note 8 at 1100 . On the Ecole Jamot, see H. Jonchère, "L'Ecole des infirmiers spécialisés du Service Générale d'Hygiène Mobile et de Prophylaxie d'A.O.F. (Ecole Jamot)," in Conférences Internationales Médicales, supra, note 25 at 107.

59 Hailey, supra, note 8 at 1087.

60 R. Girard, "La Situation sanitaire et démographique dans l'Union Française", supra, note 21 at 32 .

61 Hailey, supra, note 8 at 1088.

62 E. Séré de Rivières, Le Sénégal —Dakar, supra, note 38 at 62-63. $1-4(31)$.

631 C.I.N.A.M. - S.E.R.E.S.A., supra, note 7 at 1-4(20) - 1-4(32), esp. 1-4(30),

642 C.I.N.A.M. - S.E.R.E.S.A., supra, note 7 at 2-4(6) 2-4(15). 


\section{THE DECADE OF INDEPENDENCE}

Although the accession of Senegal to independence in 1960 led to no immediate break with colonial law, ${ }^{65}$ it gave rise to a new ideology which viewed law as one of the principal instruments of social change.66 French colonial health policy had developed in a rather ad hoc fashion. In contrast, the gradual elaboration of Senegalese public health policy since 1960 has been guided by a general legal framework.

\section{A. The General Legal Framework}

The framework for the elaboration of public health law in Senegal since independence is provided, first, by the Senegalese Constitution and, secondly, by the Development Plans of 1961, 1965 and 1969.

The Constitution of the Republic of Senegal67 proclaims in its article 6, section 1 the principle of the sacredness of the human personality and the consequent obligation of the State to respect and protect it.68 It provides further that: "The State and public collectivities have the social duty of attending to the physical and moral health of the family."69 An exception to the principle of the involiability of domicile is provided in order, by application of the law, to protect the public against, inter alia, risks of epidemic.70 The Constitution also provides for the elaboration of a comprehensive legal framework for health policy in the following terms: "Programmatic laws determine the objectives of State economic and social policy. The Plan is approved by law."71

65 P. F. Gonidec, Les Droits africains (Paris: Librarie Générale de Droit et de Jurisprudence, 1968) at 36.

66 See K. M'Baye, "Droit et développement en Afrique francophone de l'ouest" in A. Tunc, ed., Les aspects juridiques du développement économique (Paris: Librairie Dalloz, 1966) 121, at 135-64; K. M'Baye, L'expérience sénégalaise de la réforme du droit (1970), Revue internationale de droit comparé 35-42; M. Alliot, L'Afrique et le droit (1967), La Table ronde (avril) at 5.

67 Constitution de la République du Sénégal (Lois constitutionnelles nos. 63-22 du 7 Mars 1963 et 67-32 du 20 juin 1967 et 70-15 du 26 février 1970). The constitution with revisions as to 1 January 1969 is reprinted in République du Sénégal, La Justice au Sénegal, 3e édition entièrement refondue et mise à jour au premier janvier 1969 (Rufisque, Imprimerie Officielle, 1969) [hereinafter cited as La Justice au Sénégal]. The revision of 1970 did not effect any changes in respect of the law of public health but was concerned with the concentration of the executive power; see A. Diop, La Revision constitutionelle du 26 février 1970 au Sénégal, (1970), Revue Sénégalaise de Droit 33 and S. M. Ajami, Reflexions sur la deconcentration de l'exécutif au Sénégal après le révision constitutionelle de 1970 (1971), 25 Revue Juridique et Politique 247.

68 La Justice au Sénégal, supra, note 67 at 7.

69 Article 14, alinéa 2; La Justice au Sénégal, supra, note 67 at 9.

70 Article 13, alinéa 3; La Justice au Sénégal, supra, note 67 at 8.

71 Article 56, alinéa 5; La Justice au Sénégal, supra, note 67 at 19. 
Three such programmatic laws, or development plans, have been adopted in Senegal since independence. ${ }^{72}$ In view of the virtual synonymity of planning with "development" in poor countries and the importance of the development plan as an "ideal of rational reorganization",73 it is perhaps most fruitful to consider the legal aspects of public health policy in Senegal within the framework provided by these three development plans. The following discussion will consequently be divided chronologically into three sections corresponding to the respective development plans of 1961-1964, 1965-1969, and 19691973.

\section{B. The First Plan Period (1961-1965)}

In the period of the First Plan as well as during the following years since independence both the goals of national health policy and the means for achieving those goals have been incarnated in legal form.

\section{Health Policy in the Plan}

Three general problems with respect to health standards and the provision of health services preoccupied Senegalese governmental planning officials immediately following independence. First, the level of health for the Senegalese population taken as a whole was deficient. Secondly, the available health facilities were unequally spread throughout the national territory. In particular, urban areas were much better equipped than rural areas. This imbalance was accentuated by the fact that Dakar, the capital city, had from 1902 to independence been the capital of the Federation of French West Africa. Thirdly, the mortality rate was high, especially among infants because of insufficient means of combatting epidemics and their consequently rapid spread when they did break out. Poor hygiene and sanitation, inadequate diets, and the pneumonia-diarrhea complex were common. Although the

72 (a) Loi no. 61-32 du 13 mai 1961 relative au Premier Plan Quadriennal de Développement pour la période 1961-1964 [Journal Official de la République du Sénégal (herein after cited as JORS) 12 fevrier 1962]; published separately as Republique du Sénégal, Premier Plan Quadriennal de Développement pour la période de 1961-1964 (Loi No. 61-32 du 13 mai 1964) (Rufisque: Imprimerie Nationale, 1962). Reference will hereinafter be made to this separately published volume, to be cited as Premier Plan.

(b) Loi no. 65-50 du 1 juillet 1965 instituant un deuxième plan quadriennal de développement pour la période 1965-1969 [1965 JORS 802]; published separately in three volumes as République de Sénégal, Deuxieme Plan de Développement économique et social, 19651969, Vol. I: Introduction et analyse, Vol. U: Plan, Vol. III: Programmes régionaux (Paris: Imprimerie Mozart, 1965). Reference will hereinafter be made to these separately published volumes [hereinafter cited as Deuxième Plan].

(c) Loi no. 69-53 du 16 juillet 1969 instituant un troisième plan quadriennal de développement économique et social pour la période 1969-1973 [1969 JORS 980]; published separately as République du Sénégal, Ministère du Plan et de l'Industrie, Troisième Plan Quadriennal de Développement économique et social 1969-1973 (Dakar, Imprimerie A. Diop, 1969). Reference will hereinafter be made to this separately published volume [hereinafter cited as Troisième Plan, see note 5 supra.]

73 Colin Leys and Peter Marris, "Planning and Development", in Dudley Seers and Leonard Joy, eds., Development in a Divided World (Harmondsworth: Penguin Books, 1971) at 270. 
average caloric intake varied from 2300 to 2900 calories per day, the average diet was unbalanced and especially lacking in vitamins and animal proteins. ${ }^{74}$

The First Plan defined health policy priorities for the following four years. Health conditions were to be improved with special emphasis on the least protected areas, such as the region of Eastern Senegal and the rural areas generally. Following the pattern of health policy during the colonial period, preventive medicine and health education were to be emphasized. Finally, increased research was to be carried out with respect to economical means of improving human activity, the development of therapeutic medicine on a collective and relatively inexpensive basis, proper diet, and the prevention of diseases. ${ }^{75}$

In order to attain these proposed objectives the Plan outlined a number of general policies. The training of medical personnel was to be adapted to the needs of the country. Special emphasis was to be given to rural preventive medicine and rural health education as well as to the multiplicity of extrahospital functions which devolved on medical personnel in a largely rural country with extremely limited financial and human resources. To complement this reorientation of medical training the Plan called for the restructuring of health facilities. Dispensaries located throughout the country were to extend their reach beyond the urban areas in which they were located and to function as health centers for the surrounding rural areas under the direction of a chief medical officer responsible for curative medicine, maternal and infantile protection, and anti-epidemic measures for the rural area concerned. ${ }^{76}$ In order to provide even limited health facilities, particularly protection against epidemics, in sparsely populated areas, the number of mobile hygiene and prophylactic units was to be increased.77

While increasing health services the Senegalese planners hoped to avoid the multiplication of administration units. All health activities within the seven regions of the country were to be placed under the administrative responsibility of the head medical officer for each region rather than under specialised sub-regional health bureaucracies for each activity. In addition, the Plan announced that the provision of new hospital facilities would for the coming four-year period be limited to the improvements of existing facilities or the completion of those currently under construction. ${ }^{78}$

\section{Legislative Implementation}

Public health in Senegal, like numerous areas of public policy in many African countries, ${ }^{79}$ witnessed a tremendous proliferation of legislation in the

74 Premier Plan, supra, note 72 at 8 . See also M. Sankale and P. Péne, Médecine Sociale au Sénégal, supra, note 7 at 14-18.

75 Id., at 131.

76 Id. at 131.

77 ld., at 132.

78 Id. at 132 . The readjusted First Plan proposed health investments equalling 3.3\% of the total public and $2.2 \%$ of the combined public and private investments; 2 Deuxième Plan, supra, note 72 at 31.

${ }^{9}$ See Michel Alliot, L'Afrique et le droit, supra, note 66. 
immediate post-independence period. This legislation, including certain statutes enacted prior to adoption of the Plan, fell into three major areas: extension of health facilities, organisation of health services, and educational facilities. Other statutes regulated a limited number of specific questions relating to public health.

Extension of facilities. A decree organising maternal and infantile health facilities preceded the First Plan. ${ }^{80}$ This 1960 decree provided that each regional capital was to have at least one primary centre for maternal and child health, including a prenatal and postnatal examination centre, a centre for medical consultation of healthy children, a vaccination service, a dietetic service, and a centre for maternal education. ${ }^{81}$ While each population centre of 10,000 or more inhabitants was to be provided with these health facilities, 82 groupings of less than 10,000 inhabitants were to be served either by the establishment of secondary health centres or by periodic visits of personnel from primary centres. ${ }^{83}$ The opening of any private establishment receiving either pregnant women or children less than six years old was conditional on the approval of the Minister of Health and Social Affairs. ${ }^{84}$

A basic text on endemic diseases ${ }^{85}$ divided the country into zones of mobile and prophylactic hygiene for purposes of control of the following diseases considered endemic to Senegal: smallpox, yellow fever, sleeping sickness, leprosy, onchocerciasis, trachoma, syphilis, tuberculosis, bilharzia and malaria. ${ }^{86}$ It provided for periodic checks on health conditions by medical personnel, ${ }^{87}$ made periodic smallpox and yellow fever vaccinations obligatory ${ }^{88}$ and specified penalties for infractions of the statute..$^{89}$

Organisation of health services. Soon after the enactment of the First Plan, the public health service of Senegal was organized. ${ }^{90}$ For purposes of public health the country was divided into medical regions, medical circumscriptions and hospital complexes.91 The medical region, corresponding to an administrative region, ${ }^{92}$ was placed under the direction of a regional head doctor responsible for the public health of the region..$^{93}$ Each medical region was

80 Décret no. 60-247 M.S.A.S. du 13 juillet 1960 organisant la protection maternelle et infantile au Sénégal [1960 JORS 759].

81 Id., art. 6.

82 Id., art. 8, al. 2.

83 Id., art. 8, al. 3 .

84 Id., art. 14.

85 Loi no. 61-11 du 10 mars 1961 relative à la protection de la santé publique en matière de grandes endèmies [1961 JORS 421].

$86 I d$., art. 1.

$87 \mathrm{Id}$., art. 2.

88 Id., art. 5.

$89 \mathrm{Id}$., art. 6. Infractions of this statute were to be sanctioned by either imprisonment of fifteen days to three months or a fine of 1,000 to 10,000 CFA francs, or both.

90 Loi no. 61-350 M.S.A.S. du 11 septembre 1961 fixant les attributions des médecinschefs de régions médicales et de circonscriptions médicales [1961 JORS 1412].

91 ld., art. 1.

92 Id., art. 2.

93 Id., art. 3. Id., arts. 4-18 specify the duties of the head doctor of the region. 
divided into medical circumscriptions, each of which corresponded to an administrative circumscription, ${ }^{94}$ under the direction of a chief medical officer of the circumscription responsible for the public health of that area. ${ }^{95}$ After the reform of Senegalese administrative organization in $1964^{96}$ the medical circumscription corresponded to the administrative department. ${ }^{97}$ The hospital complexes were to be regulated by a prior decree. ${ }^{98}$

At the end of the period of the First Plan the Ministry of Public Health and Social Affairs of Senegal was recognized. 99 The Ministry was divided into two central services, the Direction of Public Health and the Direction of Social Affairs. ${ }^{100}$ The Direction of Public Health was given responsibility for medical assistance, including the overseeing and coordination of all health establishments, public or private, in Senegal and the operation of all gratuitous medical services; for public hygiene, including prophylactic measures against transmissible diseases, maternal and infantile protection, and mass health education; for the policing of health measures, including the control of pharmacies and pharmaceutical depots and the control of the private practice of medicine; and for the collection of medical statistics. ${ }^{101}$

Education. In accordance with the emphasis placed by the First Plan on the reorientation of health training, a wide range of statutes provided for the establishment or reorganization of educational facilities for medical personnel. Prior to the enactment of the Plan, decrees regulated admission of nursing students to the Ecole Jamot in Upper Volta ${ }^{102}$ and created a specialized degree for nurses specializing in endemic diseases. ${ }^{103}$ Subsequently a school for agents

94 Id., art. 19.

95 Id., art. 20. Id., arts. 21-23 specify the duties of this health officer.

96 Décret no. 64-282 du 4 avril 1964 portant réforme administrative [1964 JORS 587]. For a description of Senegalese administrative organisation see Jean-Claude Gautron, Droit Public au Sénégal (Paris: Editions A. Pédone, 1970) at 135-285.

97 Décret no. 64-805 du 3 décembre 1964 portant réorganisation du Ministère de la Santé et des Affaires sociales [1964 JORS 1669], art. 11. The medical region continued to correspond with the administrative region; $i d$. , art. 11.

98. Décret no. 61-350 M.S.A.S. du 11 septembre fixant les attributions des médecinschefs de régions médicales et de circonscriptions médicales [1961 JORS 1412], art. 24. The prior decree to which reference is made is Décret no. 61-216 M.S.A.D. du 31 mai 1961 portant règlement des formations hospitalières [1961 JORS 894], discussed infra.

99 Décret no. 64-805 du 3 décembre 1964 portant réorganisation du ministère de la santé publique et des affaires sociales [1964 JORS 1669], modified by: Décret no. 65-576 du 6 septembre 1965 portant modification des articles 1 à 3 du Décret no. 61-805 du 3 septembre 1964 portant réorganisation du ministère de la santé et des affaires sociales [1965 JORS 1119].

100 Décret no. 64-805 du 3 décembre 1964 portant réorganisation du ministère de la santé publique et des affaires sociales, art. 1 [1964 JORS 1669].

$101 \mathrm{Id}$., art. 4. Id., arts. 5-10 provide for the division of the Direction of Public Health into bureaus for curative and individual medicine, preventive and collective medicine, pharmacies, technical documentation, and schools and specify the functions of each.

102 Décret no. 61-020 du 11 janvier 1961 relative à l'admission des élèves infirmiers à l'école Jamot [1961 JORS 62].

103 Décret no. 61-021 du 11 janvier créant un brevêt de spécialisation des infirmiers des grandes endémies [1961 JORS 63]. 
sanitaires was organized at St. Louis ${ }^{104}$ and a training course was established for specialized male and female nurses. ${ }^{105}$

At St. Louis, the schools for nurses and midwives were recognized and a school for social welfare workers was established. ${ }^{106}$ Each school provided for three categories of students: those supported entirely by the Senegalese government, those who were self-supporting or who were supported by the government of another State, and those already employed by the Senegalese administrative bureaucracy. ${ }^{107}$ Students in the first and third categories were required upon entrance to the school to sign an undertaking to serve after graduation for ten years in the national public health service including the first five years in rural areas. ${ }^{108}$ In addition, a school for training dental specialists was established ${ }^{109}$ and a one-year course leading to a diploma in applied tropical medicine was created at the University of Dakar.110

Other questions. In this same period, a number of other laws were enacted to regulate more specific questions of public health policy. In addition to the statute on endemic diseases, ${ }^{111}$ and that on maternal and child welfare, ${ }^{112}$ several statutes provided for the sale of pharmaceutical drugs and medicines

104 Décret no. 61-217 M.S.A.S. du 31 mai 1961 portant organisation de l'école des agents sanitaires [1961 JORS 896] and modified and completed by: Décret no. 61-309 du 4 août 1961 modifiant et complétant le décret no. 61-217 M.S.A.S. du 31 mai 1961 portant organisation đe l'école des agents sanitaires [1961 JORS 1282].

105 Décret no. 61-294 đu 18 juillet 1961 portant réglementation du stage des infirmiers et infirmières spécialistes [1961 JORS 1231].

106 Décret no. 62-0137 M.S.A.S. du 3 avril 1962 portant réorganisation de l'école des sages-femmes [1962 JORS 666] [hereinafter Décret no. 62-0137 M.S.A.S.].

Décret no. 62-0138 M.S.A.S. du 3 avril 1962 portant organisation de l'école des assistantes et assistants sociaux [962 JORS 669] [hereinafter Décret no. 62-0138 M.S.A.S.].

Décret no. 62-0139 M.S.A.S. du avril 1962 portant réorganisation de l'école des infirmiers et infirmières d'Etat [1962 JORS 671] [hereinafter Décret no. 62-0139 M.S.A.S.].

107 Décret no. 62-0137 M.S.A.S., supra, note 106, art. 9; décret no. 62-0138 M.S.A.S., supra, note 106, art. 9; décret no. 62-0139 M.S.A.S., supra, note 106, art. 9.

108 Décret no. 62-0137 M.S.A.S., supra, note 106, art. 9, al. 1, art. 31, al. 1; đécret no. 62-0138 M.S.A.S., supra, note 106, art. 9, al. 1, art. 10, al. 1; décret no. 62-0139 M.S.A.S., supra, note 106, art. 9, al. 1 , art. 10, al. 1 . Severe penalties were provided for failure to carry out this obligation. In each case the person was barred from further governmental employment and obliged to reimburse the total expenditure for his training which had been underwritten by the government. Décret no. 62-0137 M.S.A.S., supra, note 106, art. 31; décret no. 62-0138 M.S.A.S., supra, note 106, art. 10; décret no. 62-0139 M.S.A.S., supra, note 106, art. 10.

109 Décret no. 63-237 M.S.A.S. du 20 avril 1963 portant organisation de l'école des mécaniciens en prothèses dentaires et maxillo-faciale [1963 JORS 643].

110 Décret no. 64-188 de 6 mars 1964 portant création d'un diplome de médecine tropicale appliquée à la faculté mixte de médecine et pharmacie de l'université de Dakar [1964 JORS 441].

111 Loi no. 61-11 du 10 mars 1961 relative à la protection de la santé publique en matière de grandes endémies [1961 JORS 421].

112 Décret no. 60-247 M.S.A.S. du 13 juillet 1960 organisant la protection maternelle et infantile au Sénégal [1960 JORS 759]. 
[VOL. 11, NO. 1

by pharmacies or depositories. ${ }^{113} \mathrm{~A}$ legal basis was provided for the establishment of leper villages, to which minor children and spouses of lepers would be admitted as well as lepers themselves and in which re-education and exploitation of land and other goods would be combined with treatment.114 Several statutes regulated the internal organization and functioning of hospitals, including the recruitment of medical personnel and the creation of a treatment, teaching and research hospital at the University of Dakar. ${ }^{115}$

A campaign against venereal disease and prostitution was initiated in 1962. ${ }^{116}$ Medical examinations were made obligatory in certain cases; ${ }^{117}$ doctors were given additional public duties in cases involving venereal disease patients, ${ }^{118}$ including the duty of recommending urgent hospitalisation when deemed necessary. ${ }^{119}$ Mandatory hospitalization upon public order was provided in cases of patients who refused to undergo treatment. ${ }^{120}$

\section{Results}

The accomplishments with respect to health services of the first five years of independence were summarized in the Second Development Plan. On the whole, less than $50 \%$ of the projects of the health sector of the First Plan

113 Décret no. 61-218 M.S.A.S. đu 31 mai 1961 réglementant la création et la gérence des dêpôts de médicaments [1961 JORS 898]; Arrêté ministérial sur la répartition des dépôts de médicaments sur le territoire de la République du Sénégal [1961 JORS 1075]; Arrêté ministériel no. 9690 M.S.A.S.-S.P.-P.H. du 26 juin 1961 réglementant la vente de l'alcool ethylique pharmaceutique [1961 JORS 1118]; Erratum à l'arrêté ministériel no. 13752 M.S.A.S. du 18 septembre 1961 réglementant la vente de l'alcool ethylique pharmaceutique [1961 JORS 1495]; Décret no. 61-366 M.S.A.S. du 21 septembre 1961 établissant un service de garde dans les localités où existent plusieurs officines de pharmacie [1961 JORS 1495]; Décret no. 61-104 M.S.A.S. du 24 octobre 1961 portant organisation des tours de garde dans les pharmacies [1961 JORS 1644]; Décret no. 62-0286 M.S.A.S. du 20 juillet 1962 fixant provisoirement le nombre et la répartition des officines de pharmacie dans la République du Sénégal [JORS du 4 août 1962. p. 1328].

114 Décret no. 65-128 du 4 mars 1965 portant organisation des villages de lépreux [1965 JORS 371]. esp. arts. 2, 3, 7.

115 Décret no. 61-216 M.S.A.S. du 31 mai 1961 portant règlement des formations hospitalières [1961 JORS 894] is the basic text. This decree was followed by: Décret no. 61-468 M.S.A.S. du 13 décembre 1961 relatif à l'internat en médecine des hopitaux de Dakar [1961 JORS 1867]; Décret no. 62-0175 M.S.A.S. du 9 mai 1962 relatif à la nomination de médecins, chirurgiens, pharmaciens-biochimistes et spécialistes des hopitaux [1962 JORS 945]; Décret no. 62-176 M.S.A.S. du 9 mai 1962 relatif à la nomination des assistants des hopitaux [1962 JORS 948] which provided, inter alia, for the continued employment of foreign technical assistance personnel, $1 d$. art. 16; Décret no. 62-0201 M.S.A.S. du 23 mai 1962 portant organisation du centre hospitalier et universitaire de Dakar [1962 JORS 999]; Décret no. 65-061 đu 4 février 1965 relatif au personnel enseignant et hospitalier du centre hospitalier universitaire de Dakar [1965 JORS 271].

116 Décret no. 62-0317 M.S.A.S. du 16 août 1962 organisant la lutte contre les maladies vénériennes [1962 JORS 1470].

117 Id., art. 2.

118 Id., art. 6, al. 2; art. 9.

119 Id., art. 10.

120 Id., arts. 11-13. Infractions of this statute were to be punished by fine, imprisonment or both: Loi no. 63-17 du 5 février 1963 portant répression des infractions au Décret no. 62-0317 du 16 août 1962 organisant la lutte contre les maladies vénériennes [1963 JORS 391]. 
were carried out.121 The programme with respect to training facilities was generally completed with the exceptions of the school for nurses at St. Louis, carried over to the Second Plan, and of the mobile health education facilities, for which sufficient funds were unavailable. Hospital renovation and completion was generally behind schedule. In particular, work on the St. Louis hospital was carried over to the Second Plan. Urban hygiene and mother and child health units were complete only at Dakar and Kaolack. ${ }^{122}$ Fifty-four percent of the rural health centre programme had been completed. The extension of mobile and prophylactic hygiene units was slower than anticipated. Facilities to combat endemic diseases were complete only at Louga. Facilities for treatment of leprosy were completed only for $23 \%$ of the First Plan programme. ${ }^{123}$

The primary reason for the failure to meet a greater proportion of Plan targets was a lack of means, both human and material. ${ }^{124}$ Extension of health facilities into rural areas was hindered by insufficient equipment, by the desire of existing medical personnel to remain in urban areas and to concentrate on curative rather than preventive medicine and by inadequate recruitment of new medical personnel. The St. Louis hospital, which accounted for almost $40 \%$ of projected health expenditures in the First Plan,125 was not yet built, since the first project of construction was abandoned.126

Although it is beyond the scope of this article to analyze the sturcture of post-secondary education in Senegal and its recent reform, at the time of the First Plan the influence of France on Senegalese post-secondary education, including medical training, was particularly strong. The number of students entering medical school at the University of Dakar was determined by the same examination used in France and the curriculum for Senegalese medical education was planned in France. ${ }^{127}$ These factors seriously limited the role of the Dakar medical faculty in meeting the health needs of Senegal, both in terms of the recruitment of sufficient numbers of medical personnel128 and in terms of the adequacy of their training with respect to the most pressing health problems of the country. 129

1211 Deuxième Plan, supra, note 72 at 34 . The percentages vary, according to the criteria chosen, from $28 \%-55 \%$ if the Saint-Louis hospital project originally envisaged is included and from $46 \%-56 \%$ if this project is omitted: $i d$. The figure of $28 \%$ realization is given also at 2 Deuxième Plan, supra, note 72 at 237.

1221 Deuxième Plan, supra, note 72 at 237.

123 Id., at 36.

1242 Deuxième Plan, supra, note 72 at 235.

125 Premier Plan, supra, note 72 at 132.

1261 Deuxième Plan, supra, note 72 at 28.

127 John Bryant, Health and the Developing World, supra, note 3 at 63-64.

128 The entering class in 1964 numbered 28, including 3 Senegalese, and the total enrollment of 132 included 22 Senegalese: $I d$., at 63.

129 The question of fit between the sociocultural context and medical education is discussed in G. M. Foster, "Cross-Cultural Medical Education: Some Social and Cultural Factors," in H. van Zile Hyde, ed., Manpower for the Nation's Health, supra, note 1 at 166. See J. Bryant, Health and The Developing World, supra, note 3 at 329-33. 


\section{The Second Plan Period (1965-1969)}

\section{Health Policy in the Plan}

The Second Development Plan of Senegal was enacted in July 1965.130 While taking note of the lack of trained personnel and of the fact that it was pointless to build dispensaries if no personnel were to be forthcoming, 131 it projected the same general goals as did the First Plan: the priority of rural over urban, of mass medicine over individual medicine, of preventive medicine over curative medicine, and of health education. ${ }^{132}$

These goals were to be met, first, by training increased numbers of medical personnel and by efforts to overcome the concentration in cities of those already trained. Rural facilities were to be increased by gradually providing each region with a hospital, by furnishing sufficient equipment to the existing 31 rural health centres, and by increasing the number of dispensaries to the extent of the availability of personnel. New hospital construction was not to be undertaken, although this stricture was of limited import given the enormous expense of completing existing facilities and the financial impossibility of undertaking new construction. ${ }^{133}$ In view of the lack of trained medical personnel and the recognition of a reluctance among youth to enter the health service, it is significant that the Second Plan noted a suggestion to reopen facilities for training medical assistants and suggested that this proposal merited further study. ${ }^{134}$

In the Second Plan the health investment budget was divided into two parts. Those projects considered to be of first priority accounted for a proposed investment expenditure of 2343 million CFA francs, while second priority projects totalled an additional 746 million CFA francs. Second priority projects were to be undertaken at the end of the Second Plan period if sufficient funds were available; if not, they were to be postponed until the Third Plan period. ${ }^{135}$

\section{Legislative Implementation}

The legislation enacted to implement this health strategy may be divided into three categories: health services, including hospitals; education and

130 Deuxième Plan, supra, note 72.

1311 Deuxième Plan, supra, note 72 at 28.

1322 Deuxieme Plan, supra, note 72 at 235 . The need for rural health education is evident in the reports of local development officials. See, for example, République du Sénégal, Ministère du Plan et du Développement, Direction de l'Animation et de l'Expansion, Région de Casamance, Département de Ziguinchor, Séminaire des Cadres Intermédiares (1966) at 2-24.

- 1332 Deuxième Plan, supra, note 72 at 235-236.

134 Id., at 248. The question of adequate medical training is closely related to biomedical technology. See W. McDermott, "Modern Medicine and the DemographicDisease Pattern of Overly Traditional Societies", supra, note 3 at 155-158 who argues that Western biomedical technology and the clinical physician system are inadapted to the disease patterns in Third World rural areas.

1352 Deuxieme Plan, supra, note 72 at 249. Total health investment expenditure comprised $2.8 \%$ of the total proposed public budget. 
training of health personnel; and the organization and regulation of the medical profession.

Health services. Legislation under the Second Plan was devoted primarily to supplementing measures enacted earlier. A ministerial order of 1965 specified measures to prevent the outbreak of yellow fever. ${ }^{136}$ Legislation was enacted to control the spread of venereal disease: prostitutes were required to register and persons afflicted with venereal disease were to be confined for purposes of treatment. ${ }^{137}$ The number and location of pharmacies was fixed by a 1966 statute which provided for sixty-eight pharmacies throughout the country. ${ }^{137 a}$ Three statutes further regulated the importation, preparation, and sale of pharmaceutical products. ${ }^{138}$

Other statutes were enacted with respect to hospitals. Several years of operation of the Dakar University hospital raised problems concerning the allocation of time by hospital personnel between teaching, research, and private medical practice. Further, the experience of hospital administration since independence necessitated other measures, such as the establishment of a hospital fee scale. All of these matters were dealt with by legislation during this period. ${ }^{339}$

Education. Assuring an adequate number of trained Senegalese health personnel has been a major problem in the delivery of health services in Senegal since independence. Not only were the majority of trained personnel of nonSenegalese, primarily French, nationality, but the medical training provided in Senegalese post-secondary institutions was little adapted to the needs of the country. Partly to remedy these deficiencies, legislation concerning medical education was enacted in the 1965-1969 period.

136 Arrêté ministêriel no. 17615 M.S.A.S.-D.T.-S. TECH. du 3 décembre 1965 fixant les mesures d'ordre général à appliquer en vue de prévenir l'éclosion de la fièvre jaune [1965 JORS 1549].

137 Loi no.66-21 du 1 février 1966 relative à la lutte contre les maladies vénériennes et la prostitution [1966 JORS].

137a Décret no. 66-188 du 16 mars 1966 fixant le nombre et la répartition des officines de pharmacie [1966 JORS 336].

138 Loi no. 67-20 du 28 février 1967 reportant la date d'application de la loi no. 65-33 du 19 mai 1965 portant modification des dispositions du Code de la santé publique relative à la préparation, à la vente et à la publicité des spécialités pharmaceutiques [1967 JORS 578]; Décret no. 67-007 du 4 janvier 1967 reglementant la présentation et la dénomination des spécialités pharmaceutiques [1967 JORS 99]; Décret no. 67-008 du 4 janvier 1967 relatif aux visas des spécialités pharmaceutiques [1967 JORS 99].

139 Décret no. 67-285 du 15 mars 1967 relatif aux services du Centre hospitalier universitaire de Dakar [1967 JORS 523]: Arrêté interministériel no. 9098 du 6 juillet 1967 fixant les conditions d'application de l'article 9 du décret no. 65-061 du 4 fevrier 1965 relatif au personnel enseignant et hospitalier du C.H.U. de Dakar [1967 JORS 1097]; Arrêté interministériel no. 9099 C.H.U. du 6 juillet 1967 fixant les obligations de service des membres du personnel enseignant et hospitalier du C.H.U. du Dakar [1967 JORS 1097]; Décret no. 65-510 du 19 juillet 1967 fixant le taux de l'indemnité de technicité pour les médecins, chirurgiens, pharmaciens, biochimistes et spécialistes des hospitaux [1965 JORS 874]; Décret no. 65-514 du 19 juillet 1965 portant modification du décret no. 61-468 du 12 décembre 1961 relatif à l'internat en médecine des hopitaux de Dakar [1965 JORS 874]; Décret no. 68-858 du 24 juillet 1968 portant modification des tarifs hospitaliers [1968 JORS 981]. 
In 1967 the Institute of Public Health was established at the University of Dakar. ${ }^{140}$ The basic purpose of this institute was "to teach the disciplines of public health and of sanitary and social welfare administration while adapting them to the training and the improvement of medical and paramedical personnel ... . who cooperate in Africa for the sanitary and social welfare of the population". ${ }^{141}$ Courses at the Institute were to be both practically and theoretically directed towards health planning, general and public health administration, epidemiology and statistics, nutrition, sanitary engineering, and preventive medicine and labour hygiene. ${ }^{142}$ Pursuant to this statute, ${ }^{143}$ this training led to a diploma of public health. ${ }^{144}$

In 1968 a Special Centre for the Teaching of Nursing Care was established at Dakar to train nurses, midwives, and social welfare workers from all Frenchspeaking African countries. ${ }^{145}$ A teaching and research institute for odontology and stomatology was created at the University of Dakar. ${ }^{146}$ The training period for nurses at the State school for nurses in Dakar was extended from two to three years. ${ }^{147}$

In order to increase recruitment of health personnel the Military Health Service School was established at Dakar"148 "to insure the recruitment and training of doctors, pharmacists, and dental surgeons destined to serve in the Military Health Service, in the National Army, or, by special assignment, in the Public Health Service."149 While the school was responsible for the military training of its students, it was also attached pedagogically to other relevant specialized faculties and institutes at the University of Dakar. ${ }^{150}$ Following graduation students were required to serve not only a period equal to that of their schooling but an additional ten years. ${ }^{151}$ This period included one year of service in the military health corps, additional service in the military or Public Health Corps, and possible further professional training. ${ }^{152}$ Those

140 Décret no. 67-1232 du 15 novembre 1967 relatif à l'Institut de santé publique de l'Université de Dakar [1967 JORS 1666].

141 Id., art. 2.

142 Id., art. 11.

143 Id., art. 12, al. 2.

144 Décret no. 67-1233 du 15 novembre 1967 instituant un diplome de santé publique à la faculté mixte de médecine et de pharmacie de l'Université de Dakar [1967 JORS 1667].

145 Décret no. 68-552 du 12 mai 1968 portant création d'un Centre de enseignement spécial de soins infirmiers [1968 JORS 609].

146 Décret no. 67-1229 du 15 novembre 1967 relatif à l'Institut d'Odontologie et de Stomatologie de faculté mixte de médecine et de pharmacie de l'Université de Dakar [1967 JORS 1663].

147 Décret no. 67-223 du 3 mars 1967 abrogeant et remplacant l'article 19 du décret no. 62-139 du 3 avril 1962 portant organisation de l'Ecole des infirmiers et des infirmières de l'Etat [1967 JORS 441].

148 Décret no. 68-927 du 28 août 1968 portant création et organisation de l'Ecole du Service de Santé militaire [1968 JORS 1114].

149 Id., art. 2, al. 2.

$150 \mathrm{Id}$., art. 2, al. 2 and al. 3.

151 Id., art. 4.

152 Id., art. 24. 
persons who, for reasons other than physical incapacity, failed to serve the requisite period were required to reimburse the expenses of their training. ${ }^{153}$

Medical profession. No statutory action with respect to the medical profession as such had been taken during the first years after independence. However, beginning in 1966 a series of statutes was enacted to provide the legal framework for the practice of medicine in Senegal. Basic legislation in 1966 established the conditions for medical practice, defined the illegal practice of medicine, provided for the private practice of medicine by public health personnel, established a Medical Association (Ordre des Médicins), and provided in some detail for its internal organization and functioning. ${ }^{154}$ With specific limited exceptions, ${ }^{155}$ practice of the profession of medicine was limited to persons fulfilling three conditions: possession of a Senegalese State diploma of Doctor of Medicine or of a foreign degree recognized as equivalent; Senegalese nationality or nationality of a State with which Senegal has concluded an international agreement according nationals of the State the right to practice medicine in Senegal; and enrollment on the list of doctors of the section or sections of the Medical Association corresponding to the type of practice in which the person was to be engaged. ${ }^{156}$ Any person not fulfilling these conditions or falling into one of the specified exceptions was engaged in the illegal practice of medicine if he took part "regularly or by general instructions, even in the presence of a doctor, in the establishment of a diagnosis or a treatment of real, alleged, acquired or congenital illnesses or surgical operations, whether by personal acts, verbal or written consultations, or any other means." 157 Such illegal practice was punishable by a fine of 20,000 to 100,000 francs or imprisonment of one to six months or both. ${ }^{158}$ With the exception of teaching and hospital personnel at the Centre hospitalier universitaire de Dakar, ${ }^{159}$ the private practice of medicine by public health service personnel was subject to exceptional authorization by the administrative authorities. Such authorization was conditional upon a determination of insufficient medical personnel in a given area and, if granted, was limited to practice after normal hours of service. ${ }^{160}$

All doctors except for active members of the military health service and technical assistance personnel ${ }^{161}$ were required to belong to the Medical Association. ${ }^{162}$ While an analysis of the internal regulation of the Medical

153 Id., arts. 6 and 7.

154 Loi no. 66-69 du 4 juillet 1966 relative à l'exercice de la médecine et à l'Ordre des médecins [1966 JORS 861].

$155 I d$., art. 2.

156 Id., art. 1.

157 Id., art. 4, al. 1(1). In contrast, a medical authority has stated that: "It is no exaggeration to say that the opposition of professional personnel to delegating responsibility to people with less training can be singled out as one of the most serious obstacles to improving health care in the world today." J. Bryant, Health and the Developing World, supra note 3 at 321.

158 Id., art. 5. Approximately 270 francs C.F.A., the Senegalese currency, is the equivalent of one Canadian dollar.

159 Id., art. 3. Regulated by separate statute.

160 Id., art. 12.

161 Id., arts. 1(3), 16.

$162 I d$., art. 16. 
Association is outside the scope of this article, it is important to note that African medical assistants holding degrees from the former Ecole Africaine de Dakar were recognized as possessing the necessary educational qualifications for the practice of medicine. ${ }^{163}$

Six months later a medical code of ethics was established by statute. ${ }^{164}$ Provision was made for the application of the basic statute on the practice of medicine. ${ }^{165}$ Another statute regulated promotions of medical personnel including promotions within the public health service. ${ }^{166}$

\section{Results}

Primarily because of the postponement of the construction of the St. Louis hospital, which accounted for nearly $46 \%$ of the revised estimated health budget for the $1965-1969$ period, the proportion of completed to proposed projects in the Second Plan was 52\%.167 Near the end of the Second Plan period Senegal had about one doctor per 24,300 inhabitants, an average that included such extremes as Cap-Vert with one doctor per 4,300 people and the Sine-Saloum with one doctor per 82,100 inhabitants. These ratios included a 56\% increase in the number of doctors in Senegal between 1961 and 1968. The number of other health personnel had increased less rapidly during that period, as the following table shows. 168

Public Health Personnel

\begin{tabular}{|c|c|c|c|c|c|c|c|c|}
\hline & 1961 & 1962 & 1963 & 1964 & 1965 & 1966 & 1967 & 1968 \\
\hline Doctors & 135 & 132 & 133 & 144 & 146 & 195 & 202 & 221 \\
\hline Pharmacists & 10 & 10 & 9 & 10 & 13 & 12 & 13 & 15 \\
\hline Dental Surgeons & 6 & 5 & 7 & 6 & 6 & 6 & 6 & 7 \\
\hline Midwives & 132 & 123 & 139 & 138 & 151 & 151 & 174 & 187 \\
\hline Nurses & 1,128 & 979 & 1,107 & 1,206 & 1,224 & 1,189 & 1,464 & 1,590 \\
\hline TOTAL: & $\overline{1,411}$ & $\overline{1,249}$ & $\overline{1,395}$ & $\overline{1,504}$ & $\overline{1,540}$ & 1,553 & $\overrightarrow{1,859}$ & 2,020 \\
\hline
\end{tabular}

Twenty-nine health centres and 247 health posts existed throughout the country. ${ }^{169}$ The number of hospital beds per unit of population stood at .92 beds per 1,000 inhabitants, again with substantial inter-regional disparities. ${ }^{170}$

163 Id., art. 52.

164 Décret no. 67-147 du 10 février 1967 instituant le code de déontologie médicale [1967 JORS 321].

165 Décret no. 68-701 du 18 juin 1968 portant application de la loi no. $66-69$ du 4 juillet 1966 relative à l'exercice de la médecine et à l'Ordre des Médecins [1968 JORS 739].

166 Décret no. 67-1090 du 30 septembre 1967 [1967 JORS 1517].

167 Troisieme Plan, supra, note 72 at 222.

168 Id. at 27.

$169 \mathrm{Id}$. at 223. The regional distribution of health centres and health posts respectuvery was as follows: Sine-Saloum 58 and 8; Thies 26 and 5; Diourbel 32 and 5; Casamance 56 and 6; Fleuve 48 and 4; Senegal-Oriental 26 and 2; id.

$170 \mathrm{Id}$. at 238. The distribution according to region of hospital beds per 1,000 inhabitants was as follows: Cap-Vert: 3.1, Thies: .26, Diourbel: .43, Sine-Saloum: .38, Casamance: 1.61 , Fleuve: 1.61 , Senegal-Oriental: .40; id. 


\section{The Third Plan Period (1969 - 1973)}

Since the elaboration of the Second Plan it had become obvious to Senegalese planners that policy proposals could only gradually, if ever, be translated into fact and that any realistic approach to development planning must take into account a relatively long period of implementation. ${ }^{171}$ It seems, further, that experience with the First Plan led to a more realistic, though in many cases more frustrating, appreciation of the planning process itself. Successive plans suggest an increasing realisation on the part of Senegalese planners that planning involved "no confrontation of a sphere of social ends with a sphere of available neutral means, but a continued interaction of necessarily incomplete programmes and prognoses, both containing political and social, as well as physical limitations."172 As Streeten has pointed out, adoption of such a perspective necessitated the replacement of a simplistic means-end model by the conception of a plan as an evolving process aiming not at an optimum but at improvements. ${ }^{173}$

Such an approach to planning was explicit in the Third Plan, which stated that "health planning during the Third Plan is situated in a long-term perspective which aims at the complete medical coverage of the country at the end of seventeen years, that is, in a little more than four more Plans."174

The general orientation and goals of the Third Plan remained approximately the same as the two previous plans. Proposed action included, in order of priority, the improvement of existing facilities, redistribution of existing personnel and a very limited amount of new construction involving primarily the completion of construction postponed from previous years. ${ }^{175}$ This orientation was heavily influenced by the increasingly unfavourable balance of trade from 1966 to 1971,176 which was in turn reflected in the proposed health investment budget. 177

Thus far in this period only seven statutes with respect to health services have been enacted. Nearly all supplemented or provided for the application

1711 Deuxième Plan, supra, note 72 at 37. "Il apparaît de plus en plus que ce premier Plan de développement national intégré a été une préparation aux Plans ultérieurs" (emphasis in original).

172 Paul Streeten, "Economic Strategies", in Seers and Joy, eds., Development in a Divided World, supra, note 73, 141 at 145.

173 Id., at $143-46$.

174 Troisième Plan, supra, note 72 at 222 . This estimate of four more Plans includes the third, fourth, fifth and sixth development plans; $i d$. The Senegalese government has taken a similar approach to the application of the more delicate land reform statute of 1964. See Commission interministérielle d'étude de l'application sur la Loi sur le Domaine National, "Principes directeurs, doctrine, méthode et programme d'application de la Loi sur le Domaine National, (7 février 1967)" in République du Sénégal, Ministère du Plan et de l'Industrie, Direction de l'Aménagement du Territoire, Loi, Décrets, Arrêtés et Circulaires concernant le Domaine National 274-84, especially 282-83 (Dakar, deuxième edition, janvier 1970).

175 Troisième Plan, supra, note 72 at 222-223.

176 See Mario Sampaio, Senegal's groundnut crop makes dramatic recovery, African Development, July 1972, at 12-13.

177 Only $1.9 \%$ of the total public and private expenditures were allocated to the health sector, all from public or mixed public-private financing: Troisième Plan, supra, note 72 at 324. 
of provisions of previous legislation. A 1969 law heralded as "a new weapon in our arsenal for combatting debauchery and venereal diseases"178 supplemented the Criminal Code by providing for imprisonment of one to three months for minors aged more than thirteen years who were found guilty of prostitution. ${ }^{179}$ A second statute provided for the application of the 1966 antivenereal disease legislation. ${ }^{180}$ Another supplemented earlier legislation with respect to the importation of special pharmaceutical drugs. ${ }^{181}$ Provision was made for automatic promotion of doctors, pharmacists, and dentists in the public health service. ${ }^{182}$ An inter-regional leper village was established.183 Ministerial orders concerned private practice by medical personnel of the C.H.U. of Dakar ${ }^{184}$ and remuneration of medical personnel. ${ }^{185}$ Finally, an earlier decree with respect to the organization of the health ministry was modified. ${ }^{186}$

By 1969 Senegal had 250 physicians, an average of one per 15,120 people; 22 dentists: 55 pharmacists; 1217 nursing personnel; and 236 midwifery personnel. ${ }^{187}$ Although these figures represent a substantial improvement in the number of medical personnel since independence, they may be placed in perspective by comparing them with analogous statistics for Canada at the same time. In 1968 - 69 Canada, with a population approximately seven times that of Senegal, had 28,163 physicians, or one per 740 people; 6,809 registered dentists; 10,622 registered pharmacists; and 84,000 nursing personnel. ${ }^{188}$

178 See Laity Niang, Chroniques législatives, 6 Revue Sénégalaise de Droit 124 (September 1969).

179 Loi no. 69-27 du 23 avril 1969 complétant le Code pénal par un article 327 bis réprimant la prostitution des mineurs de 21 ans [1969 JORS 530].

180 Décret d'application no. 69-616 du 20 mai 1969 portant application de la loi no. 66-21 du 1 fevrier 1966 relative à la lutte contre les maladies vénériennes et la prostitution [1969 JORS 682].

181 Décret no. 71-803 du 16 juillet 1971 completant le décret no. 67-008 du 4 janvier 1967 relatif aux visas des spécialités pharmatiques [1971 JORS 805].

182 Décret no. 71-110 du 8 févriér 1971 constituant promotion automatique des médecins, pharmaciens et chirurgiens- dentistes dans les corps de la Santé publique [1971 JORS 701].

183 Décret no. 68-002 du 4 janvier 1968 portant création d'un village de lépreux inter-régional de Koutal [1968 JORS 67].

184 Arrêté interministériel no. 14332 M.E.N.-M.S.P.A.S.-C.H.U. du 8 novembre 1971 fixant les conditions d'application de l'article 9 du décret no. 65-001 du 4 févriér 1965 en co qui concerne la clientèle privée de certains membres du personnel enseignant et hospitalier du centre hospitalier universitaire de Dakar [1969 JORS 1946].

185 Arrêté interministériel no. 11885 M.S.P.A.S.-CAB C.I.-2 du 16 septembre 1969 fixant le taux de rémunération mensuelle des internes et des externes des hopitaux de Dakar et des étudiants en médecine en faisant fonction, ainsi que des stagiaires hospitalières [1969 JORS 1244]; Décret no. 70-918 du 20 juillet 1970 relatif a la rémuneration des prestations du service d'hygiène et de la police sanitaire aux frontieres maritimes [1971 JORS 776].

186 Décret no. 70-895 du 16 juillet 1970 modifiant le décret no. 64-805 du 3 décembre 1964 portant reorganisation du Ministère de la Santé publique et des Affaires sociales [1970 JORS 775]. at 713.

187 Statistical Yearbook 1970 (New York: United Nations Publishing Service, 1971)

188 Id., at 714 . 


\section{CONCLUSION}

This article has described the development and present state of the contemporary Senegalese law relating to public health. In addition to delineating the principal areas of relevant legislative activity, it has also supplied a a foundation for more specialized research on legal aspects of the health consequences of development planning and policy in Senegal.

In the Republic of Senegal, as in many "developing" countries, poor health conditions and disease are common. Such conditions are obstacles to the improvement of the material and moral standards of living of the country's population. In part these conditions are the result of climate, natural environment, insufficient knowledge, and inadequate technology. At the same time they are among the consequences, largely unintended but no less direct, of changes in man's relation to his environment which fail to take into account the total ecology of change and in particular the potential health consequences of planned social changes. ${ }^{189}$ Colonial and post-independence encouragement of cash-cropping at the expense of food production and the growth of cities are examples of social changes with important consequences for health and disease.

Meeting the challenges of providing public health facilities in Senegal has required the elaboration of a legal framework for the articulation of the goals of health policy and the provision of means for the implementation of that policy. The foundation for this legal framework was largely supplied by the legacy of French colonial policy in matters of public health.

The general purposes of French colonial health policy in Africa underwent significant shifts from 1900 to 1960 . In the early years of this century the paramount concern of colonial health services was the provision of preventive and curative medical facilities for the relatively small European population in France's African colonies. As the colonial government perceived the importance of the mobilization of African labour and military forces to meet colonial needs, health services began to reorient their efforts in order to provide medical facilities for the African population. Within a centralized bureaucratic health administration, the colonial health services in French West Africa extended their reach into rural areas during the inter-war years. In contrast to the British in Africa, the French relied not on the proliferation of hospitals but on the provision of mass preventive and curative medicine through rural dispensaries.

The limited number of fully trained doctors meant that a major responsibility for the provision of health services in rural areas fell to subordinate personnel. Medical training and race coincided as criteria for distinguishing personnel in the colonial public health hierarchy. Beginning in 1918 African medical assistants, midwives, nurses and others were trained at Dakar. Even as late as 1950 all physicians were European, while subordinate personnel were largely African.

189 See C. H. Hughes and J. M. Hunter, Disease and "Development" in Africa, supra, note 8; R. F. Gray, "Medical Research: Some Anthropological Aspects", supra, note 8; S. H. Roberts, The History of French Colonial Policy, 1870-1925, supra, note 17 at 333. 
Public health policies during the colonial period were not codified in development plans until after World War II,190 and even then the plans were usually "indicative programmes". ${ }^{191}$ Since its independence in 1960 Senegal has integrated the statement of goals of public health policy and the intended means of their realization in three successive four-year development plans. These plans specify in principle the allocation of the totality of Senegal's scarce resources. Within this legal framework Senegalese public health policy has since 1960 concentrated on three general questions: the organization and provision of health services, the education of medical personnel, and the organization and regulation of the medical profession.

Generally speaking, the result of post-independence legal reforms concerning the organization of health services has been a rationalization of the centralized bureaucratic model established during the colonial period. All matters relating to public health fall within the purview of the Direction of Public Health, a subdivision of the Ministry of Public Health and Social Affairs. Senegal is divided into medical regions and medical circumscriptions which correspond to the basic administrative units of the country. The hospital of each region functions in principle as a headquarters for rural health facilities.

Improving medical facilities in rural areas has been a major concern of Senegalese health policy since independence. The means of implementing this policy have included increasing the number of dispensaries and of mobile antiepidemic units, providing for mass health education, and creating and regulating outlets for the sale of pharmaceutical products.

Despite these measures rural areas of Senegal lag far behind urban centres in the quantity and quality of health facilities. Not only do the latter possess a greater political leverage which enables them to control the allocation of scarce medical resources. Trained medical personnel most frequently prefer to practise their skills in urban centres with adequate facilities. ${ }^{192}$ This difficulty is compounded by the strong French influence on medical education in Senegal, which as a result recruits inadequate numbers of Senegalese students and tends to be theoretical and curative in orientation, and by the opposition of some Islamic religious leaders to government health programmes. ${ }^{193}$

Partly to remedy these deficiences, special attention has been given to medical education. Recent graduates of certain medical educational institutions established since 1960 are required to serve in rural areas. Institutes of

190 See J. Richard-Molard, "A propos des plans d'équipement en Afrique Noire," in Hommage d̀ Jacques Richard-Molard, 1913-1951 (Paris, Présence Africaine, 1953) 307-34. 191 Id., at 326.

192 Three-fifths of the national health budget are spent on Dakar. Four-fifths of the doctors in Senegal practice in Dakar: M. Sankalé et al, "Urbanisation et santé," supra, note 10 at 279. This imbalance is not limited to medical facilities but is common to numerous public services in Africa. See J. Bugnicourt, L'inégale répartition territoriale des agents publics dans divers états africains (1972), Revue Juridique et Politique, Independence et Coopération 233. See also B. Delbard, Les dynamismes sociaux au Sénégal (Dakar, Institut de Science économique appliquée, 1966).

193 See L. C. Behrman, Muslim Brotherhoods and Politics in Senegal (Cambridge: Harvard University Press, 1970) at 144-47. 
public health and nursing have been created to train personnel in mass preventive medicine and all aspects of practical public health work in an African context. Provision has been made for the training and recruitment of military health personnel for service in the public health corps.

Regardless of the location or type of practice, all doctors in Senegal, except for active members of the military health service and technical assistance personnel, are since 1966 required to belong to the national medical association. This association includes African medical assistants holding degrees from Dakar. The conditions for practice, the definition of the illegal practice of medicine, and a medical code of ethics have been established by statute.

It is by piecemeal legislation within the framework provided by development plans that a body of public health law has been elaborated in Senegal since independence. In the course of these development plans, the philosophy of planning, including public health planning, in Senegal has evolved from a simple ends-means calculation to a more realistic, though more long-term, process model aiming at gradual improvements in the provision of public halth facilities. Hence the Third Plan explicitly recognized that, even given current expectations as to adequate health facilities, complete medical coverage of the country would not be attained until about 1985 . Such a recognition contains both an element of self-justification and a note of realism as to the difficulties involved in the provision of adequate public health facilities with limited human and material resources. 


\section{.}

